\title{
Muslim consumers' purchase behavior towards halal cosmetic products in Malaysia
}

\author{
Ahasanul Haque ${ }^{a}$, Naila Anwarb, Arun Kumar Tarofder ${ }^{c}$, Nor Suhana Ahmad ${ }^{b}$ and Sultan Ra- \\ haman Sharif ${ }^{\mathrm{c}}$
}

${ }^{a}$ Department of Business Administration, International Islamic University Malaysia, Box No. 10, 50728, Kuala Lumpur Malaysia ${ }^{b}$ Faculty of Economics and Management Sciences, International Islamic University Malaysia, Box No. 10, 50728, Kuala Lumpur Malaysia

${ }^{c}$ Faculty of Business Management and Professional Studies, Management and Science University, 40100, Shah Alam, Selangor, Malaysia C H R O N I C L E A B S T R A C T

\begin{tabular}{l} 
Article history: \\
Received: July 25, 2018 \\
Received in revised format: Au- \\
gust 29,2018 \\
Accepted: September 20, 2018 \\
Available online: \\
September 20, 2018 \\
\hline Keywords: \\
Halal \\
Cosmetics \\
Purchase behavior \\
Muslim consumers
\end{tabular}

\begin{abstract}
Over the years, substantial efforts have been given for exploring the halal concepts particularly, in the aspect of consumable goods and services. Concerning the issue of halal cosmetic products, the majority of the studies were undertaken until the stage of consumers' purchase intention only. Comparatively, only few studies were found in the area of pertaining to Muslims' purchase behavior of halal cosmetic products. Hence, this study can be considered significant in the sense that it tries to bridge this gap in the existing literature. Therefore, this study gives some new insights to the current body of knowledge by focusing on purchase behavior of halal cosmetics. The findings of the study demonstrate that attitude, perceived behavioral control, and religiosity had significant relationships with purchase intention, whereas subjective norm had an insignificant relationship. Ultimately, the findings would be helpful for generating future researches and offering supplementary resources, especially in the Malaysian context.
\end{abstract}

\section{Introduction}

Malaysia has been importing various types of cosmetic products from a number of different manufacturers across the world and most of them are produced by non-Muslim manufacturers. Because of this reason, "halalness" has become a very notable term in issues pertaining to the production processes and ingredients of cosmetic products. Prior literature has indicated that impermissible ingredients such as alcohol and animal parts can be found in majority of the cosmetics products that are available in the market therefore, the halal status of these products remains questionable. Based on al-Quran and asSunnah, these components are considered forbidden in Islam hence, Muslims should avoid consuming them. Under such circumstances, Muslims are now experiencing hurdles in choosing consumable cosmetic products that strictly adhere to Islamic requirements. During the past few years, the issue of "halalness" concerning consumable products have gained much attention from both academicians and practitioners. The needs and preferences of Muslim market have been acknowledged especially, in regards to their consumption behavior. Many researches have been undertaken primarily concentrating on halal

* Corresponding author. Tel. : +60-172957409

E-mail address: ahasanul@,iium.edu.my (A. Haque) 
food products (Shah Alam \& Sayuti, 2011; Yunus et al., 2014) and Islamic banking services (Haron et al., 1994; Shafie et al., 2004; Amin \& Isa, 2008; Amat Taap et al., 2011). However, there is a scarcity of studies on this issue in the area of halal cosmetic products (Abd Rahman et al., 2015). On top of that, the studies that were carried out on halal cosmetics primarily emphasised on purchase intention of halal cosmetics (Abd Rahman et al., 2015; Ansari \& Mohammed, 2015; Majid et al., 2015). Therefore, there is very limited knowledge regarding the actual purchase behavior of halal cosmetic products. This indicates that there is a need to undertake more studies on the aspect of purchase behavior of halal cosmetic products (Kaur et al., 2014).

As the demand of halal cosmetic products is accelerating day by day, marketers ought to fully comprehend the factors that may affect the purchase behavior of halal cosmetics among Muslims consumers. By having a holistic knowledge in this area, marketers will be able to produce halal cosmetic products that are able to cater to the needs and preferences of the Muslim consumers. At the same time, it will also enhance brand loyalty among the Muslims. Henceforth, this particular study intends to examine the factors that may affect purchase behavior of halal cosmetic products amid Muslim consumers in Malaysia. The aim of this study is to investigate the relationship between purchase intention and purchase behavior of halal cosmetic products among Muslim consumers and to determine the relationship between attitude, subjective norm, perceived behavioral control and purchase intention of halal cosmetics products among Muslim consumers so that, it could answer the questions "What is the relationship between purchase intention and purchase behavior of halal cosmetic products among Muslim consumers?" and "What are the relationships between attitude, subjective norm, perceived behavioral control and purchase intention of halal cosmetic products among Muslim consumers?"

\section{Literature review}

\subsection{Theory of planned behavior}

When it comes to comprehending individuals' behavior and intention, one of the most renowned theories is the Theory of Planned Behavior (TPB). This respective theory was developed by Ajzen in the year 1991. In accordance to this respective theory, the actual behavior performed by individuals is the result of their intention. In line with this view, peoples' intention is a precursor of their respective behaviors. In regards to TPB, individuals' intentions are formed firstly, based on their attitude, secondly subjective norm and thirdly perceived behavioral control (PBC). Attitude denotes a person's favorable or unfavorable disposition toward a given object, subjective norm results from social pressure, whereas, $\mathrm{PBC}$ is an outcome of individuals' control beliefs whereby, it has been noted that individuals tend to perform behaviors that they believe they can control.

\subsection{Purchase intension and purchase behavior}

Purchase behavior can be defined as consumers' power of making decision for purchasing particular products and services that are available in the market (Rani, 2014). Studies have indicated that there are several internal as well as external factors affecting consumers' purchase decisions. The former includes personality, age and beliefs meanwhile the latter consists of family, trends and social class (Abdul Brosekhan \& Velayutham, 2008; Khaniwale, 2015). In accordance to that, the marketers are expected to recognize the purchase behavior of their targeted market segment and develop strategies to serve the consumers' demands. Additionally, Rani (2004) stated that purchase behavior can be classified into four different types which are (i) Programmed Behavior which entails less effort of purchase judgment such as groceries; (ii) Limited Decision Making denotes type of purchases that require few information like apparels and home appliances; (iii) Extensive Decision Making/Complex covers higher prices of products that have greater risks for example transportation and accommodation; (iv) Impulse Buying depicts unplanned purchase behavior due to sales promotion, store ambience and others. In recent times, researchers and practitioners have given much attention to the concept of "halalness" and what actually affects the buying behavior of Muslim consumers. The scope of religiosity has been widely investigated in order to determine its significance towards consumers' consumption decision. It is noted that there is a significant connection between both of them especially when the products are imported from countries 
that ignore religious sensitivity (Al-Hyari et al., 2012). In terms of halal cosmetic products, research executed by Kaur et al. (2014) exposed that subjective norm served as the dominant predictor of halal cosmetic products consumption produced by Malaysian manufacturers.

Intention is the major aspect of Theory of Planned Behavior (TPB). On the basis of this theory, the ultimate behavior of people is mirrored through their intention toward the given behavior (Ajzen, 1991). It has been further explained by Ajzen (1991) that intention is one of the major driving forces of behavior. Whereas, the ultimate performance of an individual extensively relies on his/her willingness or likelihood of performing the behavior. Based on the Theory of Planned Behavior (Ajzen, 1991), the actual behavior of an individual is specifically affected by certain antecedents particularly, attitude along with subjective norm followed by peoples' behavioral control through intention. The findings of a study conducted by Khairi et al. (2012) also disclosed that people's purchase behavior is the result of their purchase intention as the two aspects were found to be significantly associated to each other. Additionally, a study also highlighted the issue of scarcity in the current literatures particularly pertaining to the purchase behavior of halal cosmetic products (Kaur et al., 2014). Thus, this study attempts to bridge the existing gap within the scope of halal cosmetic products. Based on the above discussion, the following hypothesis is proposed:

H1: Purchase intention has a significant positive relationship with purchase behavior of halal cosmetic products.

\subsection{Antecedents of Purchase Intention}

Theory of Planned Behavior has been used in many studies that focused on individuals behavioral intention including studies strictly focusing on the intention of Muslim consumers in terms of buying both products and also services (Lada et al., 2009; Yunus et al., 2014; Awan et al., 2015; Souiden \& Jabeur, 2015; Ghadikolaei, 2016; Suki \& Salleh, 2016). By referring to the outcomes that were generated for these researches, it was observed that intention is an outcome of the influence of various types of factors.

A research was undertaken by Awan et al. (2015) in order to identify the factors that may influence Muslim consumers' intention of buying halal products. By referring to the outcomes of the study, it was mentioned that when it comes to making halal purchases; Muslim consumers are affected by social factors, personal factors and also halal logo. Another study was carried out by Souiden and Jabeur (2015) focusing on life insurance services. The study was built by taking into account customers of conventional and Islamic banks. The findings of the study showed that in the event of using life insurance the religious beliefs held by the consumers played a moderating role between attitude and purchase intention. Therefore, respondents with higher degree of adherence to Islamic beliefs were more inclined toward using the services that are offered by Islamic banks. So, they had higher intention of patronizing to the services provided by Islamic banks. Additionally, prior research has further shown that another factor, perceived behavioral control (PBC), is also of immense importance in terms of making purchases of halal food products (Bonne et al., 2007). In another study undertaken by Lada et al. (2009) in order to determine the various aspects that affect consumers' behavioral intention toward halal products, it was shown that the elements of attitude as well as subjective norms play influential roles.

When it comes to halal cosmetics products in the setting of Pakistani consumers, previous studies have shown that certain factors, particularly consumers' commitment toward their religion or in other words their religiosity, their attitude followed by subjective norms are crucial aspects that affect their intention of purchasing halal products (Ansari \& Mohammed, 2015). Besides, the relation between Malaysian consumers' willingness of buying halal cosmetics and attitude was also disclosed in the study conducted by Abd Rahman et al. (2015). The findings of the study conducted by Majid et al. (2015) showed that consumers' religious belief is among the most important factors when they are purchasing cosmetic products. 
Attitude could be described as the feeling and perception that one has towards a single thing. In regards to Theory of Reason Action and Theory of Planned Behavior (Ajzen, 1991), attitude directs one's decision and how he/she behaves in accordance to the decision made. During an effortless and swift decision making, Sanbonmatsu and Fazio (1990) supported the prior theory and revealed that attitude helps to enhance this type of decision making. Hence, marketers should take into account the role played by attitude in generating the consumers' purchase decision. Purchases among consumers will be affected by a positive attitude that they hold towards particular products and services offered in the market. Moreover, attitude can be further classified into two different categories which are attitude towards object and attitude towards behavior (Sanbonmatsu \& Fazio, 1990). For instance, due to the quality of timepiece such as Rolex, one might have a positive attitude towards it, meanwhile inverse attitude upon procuring that kind of item. For that reason, marketers should be able to apprehend the nature and characteristics of market segment when dealing with the strategies for promoting their products and services to the market.

Over the years, the concept of attitude has been acknowledged as one of the significant antecedents of consumers' behavior. A research performed by Kim and Chung (2011) revealed that there was a significant relationship between attitude and organic personal care consumption through purchase intentions. Furthermore, enhancement in purchases behavior of online buyers was due to positive attitude gained from affirmative perception and beliefs towards internet and its reliability (Joey et al., 2004). In the issues pertaining to halal market, halal certification, religiosity, marketing mix, social influences are among the possible elements that can develop positive attitude among consumers towards halal products (Kordnaeij et al., 2013). Moreover, many researchers discovered that attitude significantly affected purchase intention toward halal food products (Lada et al., 2009; Bonne et al., 2007; Shah Alam \& Sayuti, 2011). Few other studies also revealed the same results especially in the area of halal cosmetic products. Researchers such as Abd Rahman et al. (2015) and Hashim and Musa (2014) demonstrated that there was a significant relationship between consumers attitude and purchase intention. Based on the above discussions, the following hypothesis is proposed:

$\mathrm{H} 2$ : Attitude has a significant positive relationship with purchase intention of halal cosmetic products.

\subsection{Subjective Norm and Purchase Intention}

External environment plays a significant role in guiding an individual's behavior towards certain things. One example of external forces is subjective norm which can be understood as the pressures and expectations of social group which an individual belongs to (Ajzen, 1991). Among the social groups that somewhat significantly influence one's behaviors are families, peers, colleagues and professionals (Rani, 2014; Khaniwale, 2015). Most of the time, one is expected to behave and conform to what has been believed by these social groups. According to Venkatesh and Davis (2009), for the purpose of fulfilling social expectation, people might behave according to the social group that they belong to even though the behavior is unfavorable to them. Thus, marketers should acknowledge the effect of subjective norm in relation to buyers' behavior of products and services.

Many researches have been undertaken in the past years and major results were discovered on the issues of subjective norm and its impact on consumers' purchases. Family and social class as have been stated by Moutinho (1987) in his study, serve as the predictor of decisions made by the travelers. In this sense, it is understood that family as the primary social group plays a major role in nurturing individuals behavior and conduct. Few studies also managed to support the existence of inter-correlation between subjective norm and intention such as Taylor and Todd (1995) and Shah Alam and Sayuti (2011). However, few other studies revealed the absence of connection between both mentioned components (Mathieson, 1991; Lewis et al., 2003; Khare \& Varshneya, 2017). In Malaysian context, inverse results were found whereby subjective norm has always been revealed to have impact on consumers' intentions hence, it 
served as a major predictor (Mukhtar \& Butt, 2012; Lada et al., 2009; Affendi et al., 2014). In regards to the scope of Islamic Finance, a research conducted by Taib et al. (2008) demonstrated a positive correlation between subjective norm and intention to participate in diminishing partnership for home financing. In the area of halal food products, Shah Alam and Sayuti (2011) discovered that subjective norm was positively and significantly related to purchase intention of halal food products among Muslim consumers. Subsequently, studies in halal cosmetics also had parallel results and supported the previous researches conducted in other various fields as Kaur et al. (2014). Kaur et al. (2014) demonstrated that subjective norm has a positive and significant relationship with purchase intention and therefore predicting the buying decision among Muslim consumers. Hence, it is hypothesized that:

H3: Subjective norm has a significant positive relationship with purchase intention of halal cosmetic products.

\subsection{Perceived Behavioral Control and Purchase Intention}

Perceived Behavioral Control (PBC) reveals the degree to which people think that they have the ability to control the behavior that they may perform (Iakovleva et al., 2011). PBC is basically an outcome of the resources and also skills that are needed for an individual to carry out a given action (Chiou, 1999). This is mainly for the reason that people believe that they can perform a particular behavior better is they have certain factors that may facilitate them in carrying out that behavior (Ajzen, 1991). On the other hand, the unavailability of these factors may prevent them from performing the behavior (Ajzen, 1991). In the same way, it has been further explained that the aspect of PBC basically encompasses the accessibility of the resources that are needed particularly, finance as well as time and also internal aspects such as a person's level of confidence (Ajzen, 1991; Taylor \& Todd 1995; Chiou, 1999).

A study was conducted by Bonne et al. (2007) with the purpose of understanding the factors that impact the purchase of halal meat by Muslim consumers. In regards to the results of this study it was asserted by them that in terms of buying halal meat, Muslim consumers' intention is strongly related to attitude, subjective norm as well as perceived behavioral control (Bonne et al., 2007). In the literature of halal food, the association between PBC and behavioral intention was also shown by the findings of the study conducted by Bonne and Verbeke (2006). Based on the findings, they concluded that PBC is among the most vital predictors of purchase intention. In regards to the above discussion, the following hypothesis is proposed:

H4: Perceived behavioral control has a significant positive relationship with purchase intention of halal cosmetic products.

\subsection{Religiosity and Purchase Intention}

Religiosity denotes how committed a person is towards his or her religion, and such a commitment is reflected in his/her attitude and behavior (Ramly et al., 2008). Religious commitment forms the basis of consumption choice for Muslim along with Non-Muslim consumers, and it helps them choose the correct path in terms of taking informed decisions in their lives (Salman \& Siddiqui, 2011). In line with this, in the area of consumer behavior the importance of religion cannot be overlooked (Sun et al., 2012). When it comes to Muslim consumers, religion occupies a very important part as it facilitates them to distinguish between the permissible and the prohibited (Rehman \& Shabbir, 2010). The overall decision making process, starting from selecting the product to making purchases and eventually its consumption, extensively relies on individuals' degree of commitment toward their respective religion (Kharim, 2010). Prior research has revealed that consumers' choice of products is in line with their religious commitment whereby, when individuals are highly committed to their religious principles and values they are hesitant to purchase products that are deemed to be prohibited for them. On the other hand, less religiously committed people tend to ignore their religious values and get attracted toward the consumption of prohibited products. Religion basically impact the overall decision making process of an individual; their lifestyle, food consumption habit, social groups and the decisions they take in life (Khraim, 2010). 
In the past, studies were undertaken to comprehend the effect of religion on Muslim consumers' willingness towards buying products. Based on the results that were derived for these studies, it was concluded that when it comes to Muslim consumers, religiosity plays an important role in shaping the purchase intention (Said \& Hassan, 2014; Jamal \& Sharifuddin, 2015; Mukhtar \& Butt, 2012; Borzooei \& Asgari, 2013). In the research conducted by Said and Hassan (2014) a significant affiliation was demonstrated between religious commitment and halal consumption. In a study accomplished by Jamal and Sharifuddin (2015), religion moderated the association amid collectivism and consumers purchase of halal labeled products. The findings of other studies have also revealed a significant connection between Muslim consumers' religiosity and their purchase intention of halal cosmetics (Majid et al., 2015). Based on the above discussion, the following hypothesis is proposed:

H5: Religiosity has a significant positive relationship with purchase intention of halal cosmetic products.

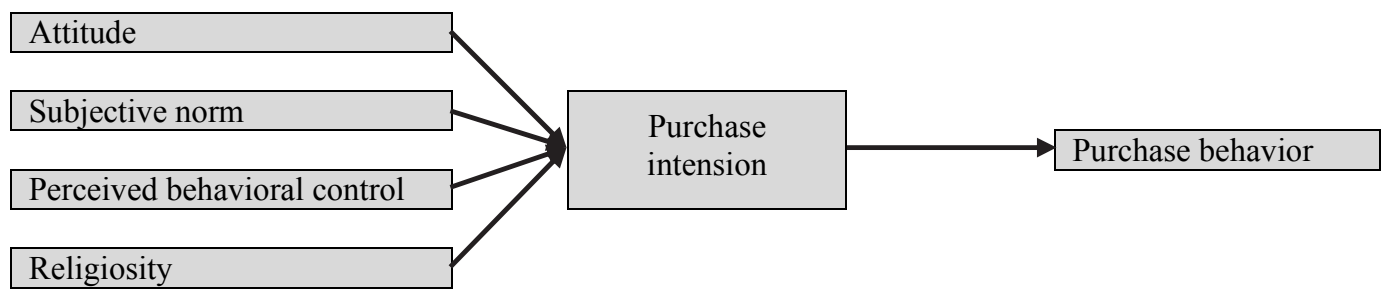

Fig. 1. Conceptual Framework of the Current Study

\section{Research method}

\subsection{Research design and Sampling techniques}

This particular research hopes to gain a thorough understanding of the factors that may affect Muslim consumers purchase behavior of halal cosmetics by using a quantitative approach. The target population of the study at hand comprises of Muslim consumers from the cities of Kuala Lumpur, Johor and Penang. These respective locations have been chosen as they are the most urbanized cities in the country. Moreover, these cities have many shopping malls with a wide array of cosmetic products. Thus, consumers residing in these cities are knowledgeable about cosmetic products, and they also have the ability to purchase such products. For the above mentioned reasons, respondents were selected from these three cities following a convenience sampling, which falls under non-probability sampling method. Convenience method has been employed because, it provides easy access to respondents; making it easier for the researchers to conduct the study within the limited timeframe (Hair et al., 2009). Additionally, this particular type of technique also allows researchers to select respondents who can provide correct information regarding the respective topic that is being studied (Hair et al., 2009). Once the selection of the population and the sampling technique is performed, it is time to determine the sample size. According to Sekaran (2003), the rule for identifying sampling size is between the range of 30 to 500, which means the sample size should be larger than 30 and less than 500. Taking this into consideration, for this research a total of 240 respondents were selected and the data were collected within a period of approximately 3 weeks. However, from the 240 sets of responses a total of 8 responses had to be discarded since, either they had missing data or were not returned back. Therefore, a total of 232 responses were used for the purpose of analysis.

\subsection{Questionnaire Design and Survey}

Survey method has been employed and primary data have been collected from the respondents by distributing hard copies of self-administered questionnaires as well as online survey through Google Form to Muslim consumers at various locations in the cities of Kuala Lumpur, Johor and Penang. In order to accomplish the objective as well as answer the research question, the primary data was gathered through 
the employment of a structured closed-ended questionnaire. The cover page of the questionnaire provided respondents with an idea of what the research is all about. At the same time, it also assured them about the confidentiality of their information. The questionnaire comprised of two sections whereby, the first section contained items pertaining to purchase behavior of halal cosmetic products, and the second section consisted of questions pertaining to the respondents' demographic characteristics. The questionnaire of this particular study was developed by adopting and modifying items from previous studies to certain extent in order to suit the needs of the current study. However, some of the items pertaining to purchase behavior were developed by the authors as there is a lack of researches consisting items for measuring this particular factor.

\section{Table 1}

Questionnaire Items

\begin{tabular}{ll}
\hline Factor & Source \\
\hline Attitude & Haque et al., 2015 \\
Religiosity & Rahman \& Shabbir, 2010; Shah Alam et al., 2011 \\
Subjective Norm & $\begin{array}{l}\text { Haque et al., 2015; Suki et al., 2014; Lada et al., 2009; Taib et al., 2008; Ven- } \\
\text { katesh \& Davis, 2000; Afendi et al., 2014 }\end{array}$ \\
Perceived Behavioral Control & Haque et al., 2015; Taylor \& Todd, 1995; Tan, 2013; Ko \& Jin, 2017; Joey, 2004 \\
Purchase Intention & $\begin{array}{l}\text { Rahman et al., 2015; Yunus et al., 2015; Amin et al., 2011; Lada et al., 2009; } \\
\text { Tan, 2013 }\end{array}$ \\
\hline Purchase Behavior & Joey, 2004 \\
\hline
\end{tabular}

Table 1 depicts the sources the questionnaire items. The questionnaire used a 5-point Likert-scale for its suitability when it comes to collecting data using a survey method as indicated by Hair et al. (2009). The scale ranged from strongly disagree to strongly agree whereby, 1 represented strongly disagree, 2 represented disagree, followed by 3 indicated neural, 4 denoted agree and lastly 5 expressed strongly agree.

\section{Results}

\subsection{Descriptive statistics}

Table 2 illustrates the demographic characteristics of the respondents.

\section{Table 2}

Demographic Profile

\begin{tabular}{|c|c|c|c|}
\hline Income & Frequency & Percentage & Cumulative Percent \\
\hline \multicolumn{4}{|l|}{ Gender } \\
\hline Male & 108 & 46.6 & 46.6 \\
\hline Female & 124 & 53.4 & 100.0 \\
\hline Total & 232 & 100.0 & \\
\hline \multicolumn{4}{|l|}{ Age } \\
\hline Below 20 & 11 & 4.7 & 4.7 \\
\hline $20-29$ & 172 & 74.1 & 78.9 \\
\hline $30-39$ & 45 & 19.4 & 98.3 \\
\hline $40-49$ & 3 & 1.3 & 99.6 \\
\hline 60 years and above & 1 & .4 & 100.0 \\
\hline Total & 232 & 100.0 & \\
\hline \multicolumn{4}{|l|}{ Marital Status } \\
\hline Single & 171 & 73.7 & 73.7 \\
\hline Married & 61 & 26.3 & 100.0 \\
\hline Total & 232 & 100.0 & \\
\hline \multicolumn{4}{|l|}{ Employment } \\
\hline Student & 184 & 79.3 & 79.3 \\
\hline NotWorking/Housewife & 8 & 3.4 & 82.8 \\
\hline Working & 40 & 17.2 & 100.0 \\
\hline Total & 232 & 100.0 & \\
\hline \multicolumn{4}{|l|}{ Highest Qualification } \\
\hline SPM/School Certificate & 20 & 8.6 & 8.6 \\
\hline Diploma & 14 & 6.0 & 14.7 \\
\hline Degree & 112 & 48.3 & 62.9 \\
\hline Masters & 59 & 25.4 & 88.4 \\
\hline PHD & 27 & 11.6 & 100.0 \\
\hline Total & 232 & 100.0 & \\
\hline
\end{tabular}


By referring to the table it can be seen that the questionnaires were distributed to a total of 232 male and female respondents (108 males and 124 females), comprising of $46.6 \%$ and $53.4 \%$. The study comprises of respondents from a wide age group which ranges from below 20 to 60 years and above. It can be observed that the majority of the participants belong to the age of 20-29 years $(74.1 \%)$ followed by 30 39 years $(19.4 \%)$, the age group of below 20 years make up $4.7 \%$. Finally, the rest of the respondents were of the age group of 40-49 years and 60 years and above each making up $1.3 \%$ and $0.4 \%$, respectively. When it comes to marital status, it can be seen that $73.7 \%$ of the respondents are single whereas, $26.3 \%$ are married. In regards to the employment held by the respondents, $79.3 \%$ of the respondents were students and another $17.2 \%$ were working, followed by not working/housewife $3.4 \%$. In terms of the highest qualification attained by the respondents, it can be seen that most of the participants (48.3\%) are degree holders followed by $25.4 \%$ holding Master's Degree, whereas $11.6 \%$ are PhD holders. Lastly, $\mathrm{SPM} /$ School Certificate holders make up to $8.6 \%$ and $6.0 \%$ are holding Diploma.

\subsection{Assessment Of Measurement Model}

After conducting EFA, the researchers proceeded with verifying the Measurement Model using Confirmatory Factor Analysis (CFA) by employing AMOS. The main reason for running the Measurement Model was to attest covariance among the latent variables.

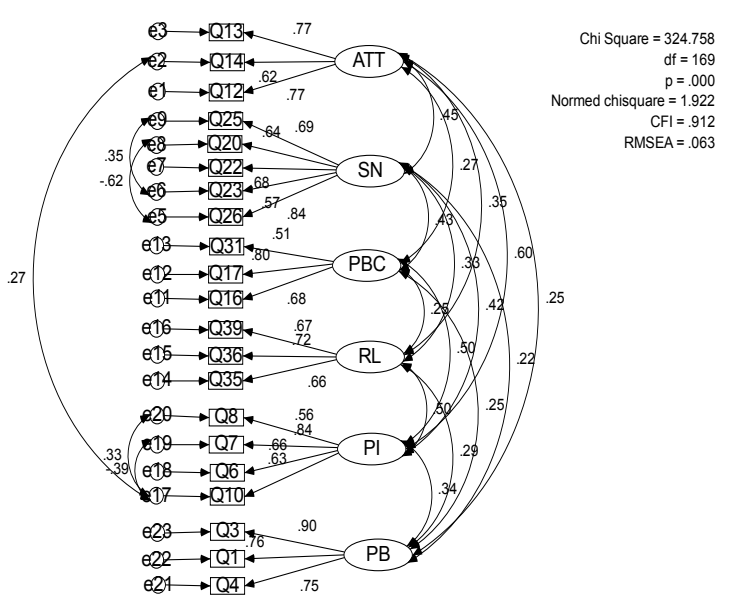

Fig. 2. Measurement Model of Purchase Behavior toward Halal Cosmetic Products

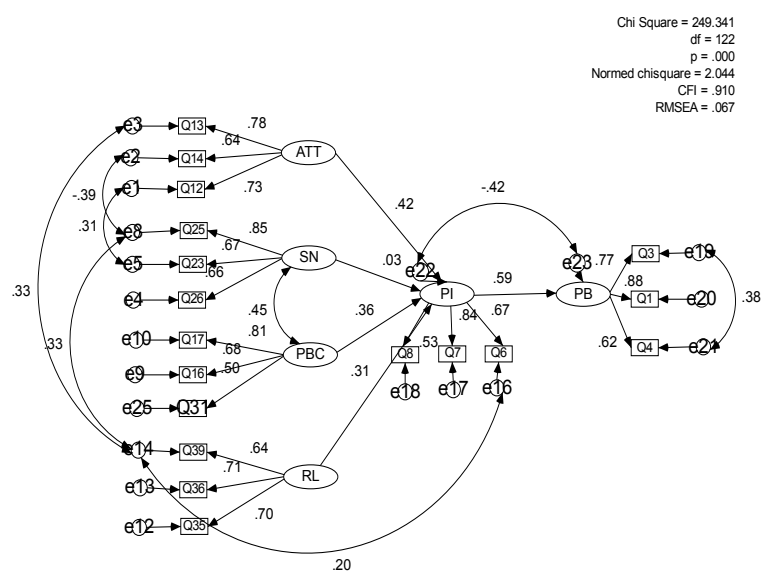

Fig. 3. Structural Model of Purchase Behavior towards Halal Cosmetic Products

Under this stage, all the variables were connected to each other in order to assess the overall fit of the model through the assessment of goodness of fit (GOF). At the initial stage of conducting the measurement model, the researchers incorporated all the 23 items that were derived from EFA. Later on, the researchers deleted the items that loaded below the threshold value of 0.50 as indicated by Hair et al. (2010). However, the values generated from the modification indices revealed that certain items were highly correlated. Henceforth, based on the largest values provided by the modification indices a number of items were connected with double headed arrows. After re-specifying the model, it was observed that the model can be considered to be fit. Based on the GOF results, it could be seen that an acceptable requirement for each of the fit indices were met even though the Chi-square statistics was significant $\left(\mathrm{x}^{2}\right.$ $324.758, \mathrm{df}=169, \mathrm{p}=.000$ ). The values attained for each of the indices are as follows: RMSEA $=.063$, $\mathrm{CFI}=.912$, Normed Chi-square $=1.922$. Based on Fig. 2 one can observe that the requirements for each of the fitness indices were achieved under the different fitness categories.

\subsection{Assessment of structural model}

Once GOF of the measurement model was within an acceptable range, the researchers continued to the next stage which was the specification of the structural model. The structural model was conducted for the main purpose of evaluating the overall fitness of the proposed full-fledged model through assigning structural relationships between constructs using AMOS. At the initial stage, all the items that were derived from the measurement model were placed according to their respective construct. Afterwards, path 
diagrams were developed based on theoretical support as indicated in Fig. 3. The GOF of the structural model was assessed through several fit indices particularly, chi-square statistics, p-value, and degree of freedom. At the same time, other fit indices namely CFI, RMSEA and Normed Chi-square were also employed. In the next stage, the researchers specified the structural model. However, at first the fitness that was attained for the model was not within an acceptable range. Henceforth, the model was refined through the use of covariance values provided by the modification indices. Thus, a few items were deleted and at the same time, some items were linked to each other with the use of double headed arrows.

This process continued until an adequately fit model was achieved by meeting all the requirements for each of the fit indices. As a significant value was attained for chi-square static $\left(x^{2}=249.341, \mathrm{df}=122\right.$, $\mathrm{p}=.000$ ), the researchers employed other types of fit indices particularly, RMSEA, CFI, Normed Chisquare. By looking at figure 3, it can be seen that all the required values for these fit indices were met RMSEA $=.067, \mathrm{CFI}=.910$, Normed Chi-square $=2.044$. Hence, it can be concluded that the structural model is fit.

\section{Reliability and Validity}

Before conducting SEM the overall measurement model should be assessed. In doing so, it has been mentioned by Hair et al. (2010) that several aspects that must be taken into account. First and foremost, in order to address the issue of unidimensionality the researchers have deleted a number of items that loaded with lower values as well as connecting items with high covariance based on the modification indices as suggested by Zainudin (2012). By observing Table 3, it can be seen that the model met all the requirements of convergent validity as all the items loaded with values greater than 0.50 . As it has been indicated by Hair et al. (2010), in terms of factor loading, 0.70 or above is considered to be an idea value however, a value of 0.50 is considered to be the minimum requirement. In terms of reliability, Cronbach's alpha and construct reliability (CR) were verified. For these two respective tests, a value between 0.60 to 0.70 must be obtained for Cronbach's alpha and concerning CR it is essential to achieve a value ranging from .60 to .70 (Hair et al., 2010).

Table 3

Convergent Validity

\begin{tabular}{|c|c|c|c|c|c|}
\hline Construct & Item & Factor Loading & Cronbach's Alpha & $\mathrm{CR}$ & AVE \\
\hline \multirow[t]{3}{*}{ Attitude } & Q13 & .77 & 0.76 & 0.85 & 0.65 \\
\hline & Q14 & .62 & & & \\
\hline & Q12 & .77 & & & \\
\hline \multirow[t]{5}{*}{ Subjective Norm } & Q25 & .69 & 0.81 & 0.68 & 0.60 \\
\hline & Q20 & .64 & & & \\
\hline & Q22 & .68 & & & \\
\hline & Q23 & .57 & & & \\
\hline & Q26 & .84 & & & \\
\hline \multirow[t]{3}{*}{ Perceived Behavioral Control } & Q31 & .51 & 0.70 & 0.67 & 0.57 \\
\hline & Q17 & .80 & & & \\
\hline & Q16 & .68 & & & \\
\hline \multirow[t]{3}{*}{ Religiosity } & Q39 & .67 & 0.72 & 0.68 & 0.60 \\
\hline & Q36 & .72 & & & \\
\hline & Q35 & .66 & & & \\
\hline \multirow[t]{4}{*}{ Purchase Intention } & Q8 & .56 & 0.76 & 0.67 & 0.59 \\
\hline & Q7 & .84 & & & \\
\hline & Q6 & .66 & & & \\
\hline & Q10 & .63 & & & \\
\hline \multirow[t]{3}{*}{ Purchase Behavior } & Q3 & .90 & 0.84 & 0.80 & 0.77 \\
\hline & Q1 & .76 & & & \\
\hline & Q4 & .75 & & & \\
\hline
\end{tabular}

Henceforth, in the context of this study the requirements for both tests were attained. When it comes to average variance extracted (AVE) a value higher than 0.50 is obligatory (Hair et al., 2010). For this 
particular study, this respective requirement has also been met as all the latent factors obtained AVE greater than 0.50 . In order to assure the issues with discriminant validity, it has been mentioned by Zainudin (2012) that this validity is met when the correlation among the exogenous constructs are less than 0.85 . Based on the CFA results, it can be observed that all the correlations between the exogenous constructs were lower than 0.85 . All minimum requirement values, reliability and validity were attained (See Table 3 and Table 4).

\section{Table 4}

Fitness Assessment of the Results Attained for Measurement Model

\begin{tabular}{lll}
\hline Category Name & Required Value & Comments \\
\hline Unidimensionality & Factor loadings for all the item $\geq 0.50$ & Minimum requirement achieved \\
Convergent Validity & AVE $\geq 0.50$ (factor loading) & Minimum requirement achieved \\
Average Variance Explained (AVE) & AVE $\geq 0.50$ & Minimum requirement achieved \\
Discriminant Validity & Correlation between exogenous constructs is $\leq 0.85$ & Minimum requirement achieved \\
Internal Reliability & Cronbach's alpha $\geq 0.60$ & Minimum requirement achieved \\
Construct Reliability & CR $\geq 0.60$ & Minimum requirement achieved \\
\hline
\end{tabular}

\section{Hypotheses Testing}

In order to verify the proposed conceptual framework that has been developed for the current study, SEM was used by the researchers. The hypotheses were assessed in accordance to the statistical output attained for the model. In total the study proposed 5 hypotheses in regards to prior findings from the literature. The outcomes of the hypothesis testing are depicted in Table 5 provided below. It indicates the values for estimates, critical ratios and significance level. By looking at the table, it can be seen that out of the 5 hypotheses that were proposed 4 were supported as they had p-values less than 0.05 and 1 was not supported.

\section{Table 5}

Result of Hypotheses Testing

\begin{tabular}{lllllll}
\hline Hypothesis & Relationship & Estimate & S.E. & C.R. & P & Result \\
\hline H1 & PI $\rightarrow$ PB & .687 & .193 & 3.566 & $* * *$ & Significant \\
H2 & ATT $\rightarrow$ PI & .505 & .101 & 4.996 & $* * *$ & Significant \\
H3 & SN $\rightarrow$ PI & .064 & .074 & .863 & .388 & Not Significant \\
H4 & PBC $\rightarrow$ PI & .394 & .102 & 3.864 & $* * *$ & Significant \\
H5 & RL $\rightarrow$ PI & .309 & .082 & 3.795 & $* * *$ & Significant \\
\hline
\end{tabular}

\section{Discussion}

Based on the Theory of Planned Behavior, intention is considered to be one of the major predictors of individuals' actual behavior (Ajzen, 1991). Moreover, in another study pertaining to halal product similar results were found whereby, purchase intention significantly affected the behavior of the consumers (Khairi et al., 2012). Similarly, a positive significant association was also found in the context of the current study hence, supporting H1. In the past, several studies were conducted in order to examine the relationship between attitude and intention. The findings of these studies have shown that there was a statistically significant connection between the two (Kim \& Chung, 2011; Lada et al., 2009; Bonne et al., 2007; Shah Alam \& Sayuti, 2011). Concerning halal cosmetics previous studies have also indicated that in terms of purchasing halal cosmetics attitude affects consumers' intention (Abd Rahman et al., 2015; Hashim \& Musa, 2014). Similar to these studies, attitude did have a significant positive relationship with purchase intention in the current study as well. Therefore, H2 is supported. A number of studies have discovered that subjective norm is significantly correlated with purchase intention (Taylor \& Todd 1995; Shah Alam \& Sayuti 2011). In Malaysia, there are several studies that demonstrated comparable findings whereby, subjective norm acts as a primary predictor of consumers' purchase intention. Regarding halal cosmetics, Kaur et al. (2014) came up with similar results among Muslim consumers. On the other hand, a number of studies revealed contradictory findings whereby, subjective norm had no effect on individuals' purchase intentions (Mathieson, 1991; Lewis et al., 2003; Khare \& Varshneya, 2017). Similar to 
these studies, subjective norm did not have a significant relationship with purchase intention in the current study as well. Therefore, H3 is not supported. In regards to past researches, perceived behavioral control (PBC) has been repeatedly found to be associated with individual's intention. Several researchers have investigated the relationship that takes place between PBC and intention. They have found the presence of significant connection amid PBC and purchase intention (Bonne et al., 2007; Bonne \& Verbeke, 2006; Khairi et al., 2012). In the case of halal cosmetic products, studies have also supported this relationship (Kaur et al., 2014). The results of the current study are also parallel to the past findings. Therefore, H4 supported. A link between religiosity and consumers' purchase intention has been observed in several studies undertaken on Muslim consumers (Mukhtar \& Butt, 2012; Borzooei \& Asgari 2013). In the same way, Ansari and Mohammed (2015) demonstrated that in the event of purchase halal cosmetics, religiosity plays a crucial role in influencing the intentions of Muslim consumers. Therefore, H5 is supported as similar result was derived for the present study as well.

\section{Conclusions}

Research has shown that the concept of halal gained much attention in the past in terms of different types of products and services pertaining to food, banking and financial services, tourism as well as fashion. Moreover, in recent years a similar trend has also been observed in the area of halal cosmetics. In terms of buying halal cosmetic products, Muslim consumers are also highly aware of the "halalness" of the products. The demand of halal cosmetic products has up surged among Muslim consumers at large. This particular occurrence has signaled that marketers should comprehend the importance of Muslim consumers' purchase behavior toward halal cosmetic products. Henceforth, the current study was undertaken in order to examine what actually affects Muslim consumers' behavior towards purchasing halal cosmetic products. In accordance to the findings several important aspects can be observed. First and foremost, the outcomes of the study have demonstrated that several factors particularly attitude, perceived behavioral control as well as religiosity are significantly associated to Muslim Malaysian consumers' intention of purchasing halal cosmetic products, and in turn purchase intention shares a meaningful relationship with consumers' actual purchase behavior toward halal cosmetics products. However, contradicting to majority of prior findings, subjective norm was found to have no relationship with Muslim Malaysian consumers' intention to purchase halal cosmetic products.

\section{Managerial implications}

Based on the findings of the study a number of managerial implications can be determined. First and foremost, the marketers should take into account the consumers' attitude towards halal cosmetic products. As attitude was found to have a significant effect of consumers purchase intention, it is important for marketers to work on gaining positive attitude towards their products. Thus, marketers in this industry should develop their cosmetic products by enhancing the image of their products and brand as a whole so that they can capture the Muslim consumers. Under such circumstances, in order to create positive attitude among the Muslim consumer it is recommended that marketers associate their products with Islamic values and requirements such as certificated halal logo and ingredients. In addition to this, despite the fact that in the case of this study subjective norm did not affect consumers' intention in buying halal cosmetic products. However, the issues pertaining to this aspect should not be totally neglected by marketers. This is for the reason that, the environment and society at large play an important role in influencing individuals' behavior. Therefore, marketers should also work toward enhancing the social acceptability of their products. They must make sure that their products and marketing strategies adhere to Islamic values.

The findings have also shown that in terms of buying halal cosmetic products, Muslim consumers perceived behavioral control affects their intentions. Hence, it is advisable for marketers to make their products easy accessible as well as affordable for their respective target customers. At the same time, in order to encourage consumers to purchase their products they should make sure that the products are safe and environmentally friendly. Another important factor that affects Muslim consumers' intention of purchasing halal cosmetic products is religiosity. Based on this finding it is suggested that marketers highly take into consideration the religious beliefs and values of the Muslim consumers. Under any circumstances, 
they should not violate the Muslim consumers' religious sensitivity. Lastly, all in all marketers who are selling cosmetic products to Muslim consumers specifically in Malaysia should try their very best in creating positive intention toward their products. This is because the presence of positive intention will lead to positive purchase behavior toward their products.

\section{References}

Abd Rahman, A., Asrarhaghighi, E., \& Ab Rahman, S. (2015). Consumers and Halal cosmetic products: knowledge, religiosity, attitude and intention. Journal of Islamic Marketing, 6(1), 148-163.

Abdul Brosekhan, A., \& Velayutham, M. (2008). Consumer buying behavior - a literature review. IOSR Journal of Business and Management, 9(1), 8-16.

Afendi, N. A., Azizan, F. L., \& Darami, A. I. (2014). Determinants of halal purchase intention: case in perlis. International Journal of Business and Social Research, 4(5), 118-123.

Ajzen, I. (1991). The theory of planned behavior. Organizational Behavior and Human Decision Processes, 50(2), 179-211.

Al-Hyari, K., Alnsour, M., Al-Weshah, G., \& Haffar, M. (2012). Religious beliefs and consumer behavior: from loyalty to boycotts. Journal of Islamic Marketing, 3(2), 155-174.

Amat Taap, M., Choy Chong, S., Kumar, M., \& Kee Fong, T. (2011). Measuring service quality of conventional and Islamic banks: a comparative analysis. International Journal of Quality and Reliability Management, 28(8), 822-840.

Amin, M., \& Isa, Z. (2008). An examination of the relationship between service quality perception and customer satisfaction: A SEM approach towards Malaysian Islamic banking. International Journal of Islamic and Middle Eastern Finance and Management, 1(3), 191-209.

Ansari, N. U., \& Mohammed, H. (2015). Factors affecting the intent to purchase halal personal care products: empirical evidence from Pakistan. International Journal of Islamic Marketing and Branding, 1(2), 199-213.

Awan, H. M., Siddiquei, A. N., \& Haider, Z. (2015). Factors affecting Halal purchase intention-evidence from Pakistan's Halal food sector. Management Research Review, 38(6), 640-660.

Borzooei, M., \& Asgari, M. (2013). The Halal brand personality and its effect on purchase intention. Interdisciplinary Journal of Contemporary Research in Business, 5(3), 481-492.

Bonne, K., \& Verbeke, W. (2006). Muslim consumer's attitude towards meat consumption in Belgium: insights from a means-end chain approach, Anthropology of Food, 5, 2-24.

Bonne, K., Vermeir, I., Bergeaud-Blackler, F., \& Verbeke, W. (2007) Determinants of Halal meat consumption in France. British Food Journal, 109(5), 367-386.

Chiou, J. S. (1999). The effects of attitude, subjective norm, and perceived behavioral control on consumers' purchase intentions: The moderating effects of product knowledge and attention to social comparison information. Proceedings of the National Science Council, Republic of China (C), 9(2), 298-308.

Ghadikolaei, F. S. (2016). The effect of halal signs and symptoms on consumers' purchase intention in Muslim and non-Muslim countries- a review. International Journal of Business and Management Invention, $5(7), 44-49$.

Hair, J. F., Bush, R. P., \& Ortinau, D. J. (2009). Marketing research: in a digital information environment (4th edn.). New York, NY: McGraw-Hill/Irwin.

Hair, J.F., Black, W.C., Babin, B.J., \& Anderson, R.E. (2010). Multivariate Data Analysis (7th edn.). New Jersey: Pearson Prentice Hall.

Haque, A., Sarwar, A., Yasmin, F., Tarofder, A. K., \& Hossain, M. A. (2015). Non-Muslim consumers' perception toward purchasing halal food products in Malaysia. Journal of Islamic Marketing, 6(1), 133-147.

Haron, S., Ahmad, N., \& Planisek, S. L. (1994). Bank patronage factors of Muslim and non-Muslim customers. International Journal of Bank Marketing, 12(1), 32-40. 
Hashim, C. M., \& Musa, R. (2014). Factors influencing attitude towards halal cosmetic among young adult urban Muslim women: a focus group analysis. Procedia - Social and Behavioral Sciences, $130,129-134$.

Iakovleva, T., Kolvereid, L., \& Stephan, U. (2011). Entrepreneurial intentions in developing and developed countries. Education + Training, 53(5), 353-370.

Jamal, A., \& Sharifuddin, J. (2015). Perceived value and perceived usefulness of halal labeling: The role of religion and culture. Journal of Business Research, 68(5), 933-941.

Joey, F., \& George, J. F. (2004). The theory of planned behavior and Internet purchasing. Internet Research, 14(3), 198-212.

Kaur, K., Osman, S., \& Maziha, S. (2014). Predicting working women purchasing behavior of Malaysian halal cosmetic products by using Theory of Planned Behavior. International Academic Research Journal of Business and Management, 3(1), 1-7.

Khairi, M. O., Nik Mat, N. K., Imhemed, G. A., \& Ahamed Ali, F. M. (2012). The direct effects of halal product actual purchase antecedents among the international Muslim consumers. American Journal of Economics, 2, 87-92.

Khaniwale, M. (2015). Consumer buying behavior. International Journal of Innovation and Scientific Research, 14(2), 278-286.

Khare, A., \& Varshneya, G. (2017). Antecedents to organic cotton clothing purchase behavior: study on Indian youth. Journal of Fashion Marketing and Management: An International Journal, 21(1), 5169.

Khraim, H. (2010). Measuring religiosity in consumer research from an Islamic perspective. International Journal of Marketing Studies, 2(2), 166-179.

Kim, H. Y., \& Chung, J-E. (2011). Consumer purchase intention for organic personal care products. Journal of Consumer Marketing, 28(1), 40-47.

Ko, S. B., \& Jin, B. (2017). Predictors of purchase intention toward green apparel products: a crosscultural investigation in the US and China. Journal of Fashion Marketing and Management: An International Journal, 21(1), 70-87.

Kordnaeij, A., Askaripoor, H. and Bakhshizadeh, A. (2013). Studying affecting factors on customers' attitude toward products with halal brand (Case study: Kuala Lumpur, Malaysia). International Research Journal of Applied and Basic Sciences, 4(10), 3138-3145.

Lada, S., Harvey Tanakinjal, G., \& Amin, H. (2009). Predicting intention to choose halal products using theory of reasoned action. International Journal of Islamic and Middle Eastern Finance and Management, 2(1), 66-76.

Lewis, W., Agarwal, R., \& Sambamurthy, V. (2003). Sources of influence on beliefs about information technology use: an empirical study of knowledge workers. MIS Quarterly, 27(4), 657-78.

Majid, M. B., Sabir, I., \& Ashraf, T. (2015). Consumer purchase intention towards halal cosmetics and personal care products in Pakistan. Global Journal of Research in Business and Management, 1(1), 47-55.

Mathieson, K. (1991). Predicting user intention: comparing the technology acceptance model with the theory of planned behavior. Information Systems Research, 2(3), 173-191.

Moutinho, L. (1987). Consumer behavior in tourism. European Journal of Marketing, 21(10), 5-44.

Mukhtar, A., \& Butt, M. M. (2012). Intention to choose Halal products: the role of religiosity. Journal of Islamic Marketing, 3(2), 108-120.

Ramly, Z., Chai, L. T., \& Lum, C. K. (2008). Religiosity as a predictor of consumer ethical behavior: Some evidence from young consumers from Malaysia. Journal of Business Systems, Governance and Ethics, 3(4), 43-56.

Rani, P. (2014). Factors influencing consumer behavior. International Journal of Current Research and Academic Review, 2(9), 52-61.

Rehman, A., and Shabbir, M. S. (2010). The relationship between religiosity and new product adoption. Journal of Islamic Marketing, 1(1), 63-69. 
Said, M., and Hassan, F. (2014). The antecendents of halal consumption congruence (HaCC) of Malaysia's halal food products: A conceptual approach. Abstract of Emerging Trends in Scientific Research, 130, 120-128.

Salman, F., \& Siddiqui, K. (2011). An exploratory study for measuring consumer awareness and perceptions towards halal food in Pakistan. Interdisciplinary Journal of Contemporary Research in Business, $3(2), 639-652$

Sanbonmatsu, D. M., \& Fazio R. H. (1990). The role of attitudes in memory-based decision making. Journal of Personality and Social Psychology, 59(4), 614-622.

Sekaran, U. (2003). Research methods for business: A skill building approach (4th edn.). New York John Wiley and Sons, Inc.

Shafie, S., Azmi, W. N. W., \& Haron, S. (2004). Adopting and measuring customer service quality in Islamic banks. Journal of Muamalat and Islamic Finance Research, 1(1), 1-12.

Shah Alam, S., \& Mohamed Sayuti, N. (2011). Applying the theory of planned behavior (TPB) in halal food purchasing. International Journal of Commerce and Management, 21(1), 8-20.

Souiden, N., \& Jabeur, Y. (2015). The impact of Islamic beliefs on consumers' attitudes and purchase intentions of life insurance. International Journal of Bank Marketing, 33(4), 423-441.

Suki, N. M., \& Salleh, A. S. A. (2016). Does Halal image strengthen consumer intention to patronize Halal stores? Journal of Islamic Marketing, 7(1), 120-132.

Sun, S., Goh, T., Fam, K. S., Xue, Y., \& Xue, Y. (2012). The influence of religion on Islamic mobile phone banking services adoption. Journal of Islamic Marketing, 3(1), 81-98.

Taib, F.M., Ramayah, T., \& Razak, D.A. (2008). Factor influencing intention to use diminishing partnership home financing. International Journal of Islamic and Middle Eastern Finance and Management, $1(3), 235-48$.

Tan, T. H. (2013). Use of structural equation modeling to predict the intention to purchase green and sustainable homes in Malaysia. Asian Social Science, 9(10), 181-191.

Taylor, S., \& Todd, P. (1995). Decomposition and crossover effects in the theory of planned behavior: A study of consumer adoption intentions. International Journal of Research in Marketing, 12(2), 137155.

Venkatesh, V., \& Davis, F. D. (2000). A theoretical extension of the technology acceptance model: Four longitudinal field studies. Management Science, 46(2), 186-204.

Yunus, N. S. N. M., Rashid, W. E. W., Ariffin, N. M., \& Rashid, N. M. (2014). Muslim's Purchase Intention towards Non-Muslim's Halal Packaged Food Manufacturer. Procedia-Social and Behavioral Sciences, 130, 145-154.

Zainudin, A. (2012). A handbook on SEM: Structural equation modelling (4th edn.). Kelantan: Universiti Teknologi MARA.

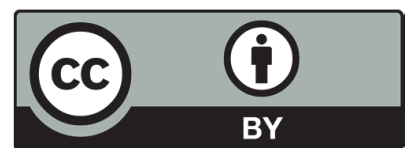

(C) 2018 by the authors; licensee Growing Science, Canada. This is an open access article distributed under the terms and conditions of the Creative Commons Attribution (CCBY) license (http://creativecommons.org/licenses/by/4.0/). 